\title{
Concentrations of Cadmium, Lead and Mercury in Raw Bovine, Ovine, Caprine, Buffalo and Camel Milk
}

\author{
Pouya Parsaei ${ }^{1,2}$ Ebrahim Rahimi ${ }^{1,2 *}$, Amir Shakerian ${ }^{1,2}$ \\ ${ }^{1}$ Department of Food Hygiene, Faculty of Veterinary Medicine, Shahrekord Branch, \\ Islamic Azad University, Shahrekord, Iran. \\ ${ }^{2}$ Research Center of Nutrition and Organic Products, Shahrekord Branch, \\ Islamic Azad University, Shahrekord, Iran.
}

Received: 2 July 2018

Accepted: 3 September 2018

\begin{abstract}
Toxic heavy metals and especially lead $(\mathrm{Pb})$, cadmium $(\mathrm{Cd})$ and mercury $(\mathrm{Hg})$ can easily transmit to humans through consumption of contaminated milk. The present research was done to study the concentrations of $\mathrm{Pb}, \mathrm{Cd}$ and $\mathrm{Hg}$ in different types of milk samples. In total, 1100 bovine, ovine, caprine, buffalo and camel raw milk samples were collected in different regions of Iran and analyzed to determine concentrations of $\mathrm{Pb}, \mathrm{Cd}$ and $\mathrm{Hg}$ by a graphite furnace atomic absorption spectrometric method. The mean recoveries of the analytical method were $88 \%, 93 \%$, and $96 \%$, for $\mathrm{Hg}, \mathrm{Cd}$ and $\mathrm{Pb}$, respectively. The mean $\mathrm{Cd}, \mathrm{Pb}$ and $\mathrm{Hg}$ contents obtained from 1100 samples were $3.62 \pm 0.35 \mathrm{ppb}$ (range: 0.06-14.03 ppb), $11.73 \pm 1.09 \mathrm{ppb}$ (range: $0.12-33.62 \mathrm{ppb}$ ) and 4.35 $\pm 0.42 \mathrm{ppb}$ (range: $1.03-10.38 \mathrm{ppb}$ ), respectively. The highest concentrations of $\mathrm{Cd}, \mathrm{Pb}$ and $\mathrm{Hg}$ were found in raw bovine samples $(4.05 \pm 0.38$, $12.36 \pm 1.21$ and $5.76 \pm 0.53 \mathrm{ppb}$, respectively), while raw camel milk harbored the lowest concentrations of heavy metals. Milk of $5 \leq$ year-old animals had the highest concentrations of $\mathrm{Cd}, \mathrm{Pb}$ and $\mathrm{Hg}$. Milk samples of all studied animals collected in spring had the highest concentrations of $\mathrm{Cd}, \mathrm{Pb}$ and $\mathrm{Hg}$ heavy metals $(P<0.05)$. The mean concentrations of $\mathrm{Cd}$ and $\mathrm{Hg}$ heavy metals were lower than the allowed limits announced by the standard organizations, while those of $\mathrm{Pb}$ were higher. These results highlight the importance of periodically monitoring levels of $\mathrm{Cd}, \mathrm{Pb}$ and $\mathrm{Hg}$ heavy metals in milk of bovine, ovine, caprine, buffalo and camel - especially in spring and summer seasons and also in $5 \leq$ year-old animals in Iran.
\end{abstract}

Keywords: cadmium, lead. mercury, raw milk, seasons, age

*e-mail: Ebrahimrahimi55@yahoo.com 


\section{Introduction}

Dairy products, and in particular milk, contain diversity of important nutrients such as proteins (casein, lactoglobulin, lactoalbumin), carbohydrates (lactose, glucose and galactose), fats (linoleic, linolenic, mystiric, palmitic, and oleic acids), minerals (calcium, phosphate, magnesium, sodium, potassium, citrate and chlorine), and vitamins (A, B, D, E, K) which are crucial to maintaining a healthy life of every individual [1]. There is evidence that milk and other dairy products might contain varying amounts of different toxic contaminants and especially heavy metals [2]. Heavy metals are defined as metallic elements that have a relatively high density compared to water [2-4]. Heavy metal pollution is a result of increasing industrialization throughout the world, which has penetrated into all sectors of the food industry. Industrial, agricultural, domestic and technological processes have resulted in an increased concentration of heavy metals in air, water, soil and subsequently, these metals are taken by plants or animals and find their ways into food chain [2-4]. Milk of animal species can become contaminated with toxic heavy metals and especially cadmium $(\mathrm{Cd})$, lead $(\mathrm{Pb})$ and mercury $(\mathrm{Hg})$ due to their feeding with contaminated forage and water and also their grazing in contaminated areas [2-4]. Chronic and even acute exposure to mercury, lead and cadmium is responsible for the occurrence of several types of cancers, tumors, autoimmune diseases, oxidative stress, enzymatic disorders, iron deficiency and hepatic and renal toxicities [5-8]. From a toxicological view, Iran is one of the main regions with boosted toxic heavy metals content [7]. Several studies have reported the high contents of $\mathrm{Cd}, \mathrm{Pb}$ and $\mathrm{Hg}$ elements in different types of food samples in Iran [7]. From a public health prospective, it is important to assess the concentrations of $\mathrm{Pb}, \mathrm{Cd}$ and $\mathrm{Hg}$ toxic heavy metals in milk. Thus, the present investigation was done to study the concentrations of $\mathrm{Pb}, \mathrm{Cd}$ and $\mathrm{Hg}$ in raw bovine, ovine, caprine, buffalo and camel milk samples collected from different parts of Iran.

\section{Materials and Methods}

\section{Samples and Study Population}

The protocol for collection of milk samples was designed to minimize any outer contamination. From January 2017 to January 2018, a total of 1100 raw milk samples including bovine $(\mathrm{n}=300)$, ovine $(\mathrm{n}=250)$, caprine $(\mathrm{n}=250)$, buffalo $(\mathrm{n}=150)$ and camel $(\mathrm{n}=150)$ (2-5-year-old animals) were randomly collected from the dairy farms of Isfahan Province, Iran, located at the center of $\operatorname{Iran}\left(32.6546^{\circ} \mathrm{N}, 51.6680^{\circ} \mathrm{E}\right)$. The province covers an area of approximately $107,027 \mathrm{~km}^{2}$ and is situated in the center of the country. It has population of 4,500,000. All animals had similar lactation stages.
Ovine and caprine milk samples were collected through the spring and summer seasons. Additionally, animals of the same species had similar breeds. Bovines whose their milk samples were collected for this study had routine feed of pellet and forage. Ovine and caprine, whose their milk samples were collected for this study, had free grazing and feed from natural forage, and plants grew on pastureland. Bovines whose milk samples were collected for this study had free grazing and feed from natural forage and thorns in the desert. Fifty $\mathrm{ml}$ of each milk sample was purchased and immediately transferred to a laboratory. In order to clear any remaining mineral elements from the laboratory tubes, dishes and glassware used in this study, all of them were immersed in $1 \%$ nitric acid (Merck, Germany) overnight and rinsed well with deionized water. Moreover, in order to clear additional remaining mineral elements we used microwave mineralizer (MLS 1200 mega). Samples were subsequently subsampled in aliquots of about $50 \mathrm{~mL}$ in Falcon tubes (free polypropylene) and stored in a refrigerator at $-20^{\circ} \mathrm{C}$ until the moment of analysis.

\section{Sample Preparation}

Twenty-five $\mathrm{g}$ of each sample was weighed in ceramic crucibles and dried at $450^{\circ} \mathrm{C}$ by a heater. Then the crucibles were put on a flame and burnt. After that, crucibles containing the samples were put in an oven at $450^{\circ} \mathrm{C}$ for 4 hours until the sample turned to ash. In the next step, $0.1 \mathrm{~mol}$ of nitric acid was added to the vessel containing the sample. Then it was flattened in a balloon and the volume was increased to $50 \mathrm{ml}$ with nitric acid 0.1 molar. In the next step, $20 \mathrm{ml}$ of each sample was transferred into a funnel decanter (separation), a few drops of Bromocresol were added to the detector, and eventually $4 \mathrm{ml}$ of citric acid was added. $\mathrm{pH}$ was regulated at 5.4 by ammonia.

\section{Analytical Procedure}

Mercury was determined in all the digests using cold vapor atomic absorption spectrophotometry flow infection mercury/hydride analyzer (FIAS 4100, Perkin Elmer, Foster City, CA, USA), equipped with a weigh hollow cathode mercury lamp operated at a wavelength of $253.7 \mathrm{~nm}$. Quartz absorption cell was used for mercury determination. The concentrations of cadmium and lead were determined by graphite furnace atomic absorption spectrophotometry (Perkin Elmer 4100), employing paralytic platform graphite tubes (Perkin Elmer, AS-40), ascorbic acid and palladium for matrix modification. Details of the analytical methods have been previously published [9]. The detection limits calculated as three times the SD were 0.11, 0.041 and $0.039 \mathrm{mg} / \mathrm{L}$ of milk for mercury, cadmium and lead, respectively. The accuracy of the analysis was checked by various methods, including the use of reference material (BCR No 150). The mean recoveries of 
Table 1. Concentrations of toxic heavy metals in different types of raw milk samples.

\begin{tabular}{|c|c|c|c|c|c|c|c|}
\hline \multirow{3}{*}{$\begin{array}{c}\text { Types of } \\
\text { milk samples }\end{array}$} & \multirow{3}{*}{$\begin{array}{l}\text { No samples } \\
\text { collected }\end{array}$} & \multicolumn{6}{|c|}{ Concentrations of heavy metals (ppb) } \\
\hline & & \multicolumn{2}{|c|}{$\mathrm{Cd}$} & \multicolumn{2}{|c|}{$\mathrm{Pb}$} & \multicolumn{2}{|c|}{$\mathrm{Hg}$} \\
\hline & & Mean \pm SD & Range & Mean \pm SD & Range & Mean \pm SD & Range \\
\hline Bovine & 300 & $4.05 \pm 0.38^{\mathrm{a}}$ & $0.16-14.03$ & $12.36 \pm 1.21^{\mathrm{a}}$ & $0.80-33.62$ & $5.76 \pm 0.53^{\mathrm{a}}$ & $2.36-10.38$ \\
\hline Ovine & 250 & $3.41 \pm 0.31^{\mathrm{b}}$ & $0.15-11.55$ & $11.94 \pm 1.92^{\mathrm{a}}$ & $0.60-29.96$ & $5.44 \pm 5.37^{\mathrm{a}}$ & $2.29-9.60$ \\
\hline Caprine & 250 & $3.22 \pm 0.31^{\mathrm{b}}$ & $0.12-10.88$ & $10.25 \pm 1.01^{\mathrm{a}}$ & $0.53-27.48$ & $5.10 \pm 0.50^{\mathrm{a}}$ & $2.10-8.98$ \\
\hline Camel & 150 & $1.22 \pm 0.11^{\mathrm{c}}$ & $0.06-4.25$ & $3.14 \pm 0.26^{b}$ & $0.12-16.74$ & $2.36 \pm 0.21^{\mathrm{b}}$ & $1.03-5.61$ \\
\hline Buffalo & 150 & $3.73 \pm 0.34^{\mathrm{b}}$ & $0.15-13.28$ & $12.04 \pm 1.19^{\mathrm{a}}$ & $0.71-29.77$ & $5.52 \pm 0.44^{\mathrm{a}}$ & $2.27-10.11$ \\
\hline Total & 1100 & $3.62 \pm 0.35$ & $0.06-14.03$ & $11.73 \pm 1.09$ & $0.12-33.62$ & $4.35 \pm 0.42$ & $1.03-10.38$ \\
\hline
\end{tabular}

*Dissimilar small leathers in each column shows significant statistical difference $(P<0.05)$.

mercury, cadmium, and lead were $88 \%, 93 \%$, and $96 \%$, respectively [9].

\section{Statistical Analysis}

Concentrations were expressed as mean $\pm \mathrm{SD}$. Statistical analysis was done using the SPSS 21.0 statistical software (SPSS Inc., Chicago, IL, USA). A t-test analytical method was performed and differences were considered significant at $P<0.05$. For statistical analysis, values below the detection limit were set to half that level.

\section{Results and Discussion}

The increase in agricultural production efficiency causes using large quantities of chemical products not even in animal feed production, but also on farms with milk production. Due to non-compliance with the right

Table 2. Senile distribution of toxic heavy metals in different types of raw milk samples.

\begin{tabular}{|c|c|c|c|c|}
\hline \multirow{2}{*}{$\begin{array}{l}\text { Types of milk } \\
\text { samples }\end{array}$} & \multirow{2}{*}{ Age (Year) } & \multicolumn{3}{|c|}{ Concentrations of heavy metals (Mean $\pm \mathrm{SD}$, ppb) } \\
\hline & & $\mathrm{Cd}$ & $\mathrm{Pb}$ & $\mathrm{Hg}$ \\
\hline \multirow{4}{*}{ Bovine } & $\leq 2$ & $1.07 \pm 0.09^{\mathrm{d}}$ & $3.29 \pm 0.35^{\mathrm{f}}$ & $2.98 \pm 0.14^{\mathrm{bc}}$ \\
\hline & 3 & $3.12 \pm 0.27^{\mathrm{c}}$ & $9.82 \pm 0.84^{\mathrm{e}}$ & $5.21 \pm 0.37^{\mathrm{ab}}$ \\
\hline & 4 & $6.19 \pm 0.58^{b}$ & $14.30 \pm 1.36^{\mathrm{c}}$ & $6.10 \pm 0.60^{\mathrm{ab}}$ \\
\hline & $5 \leq$ & $10.33 \pm 1.26^{\mathrm{a}}$ & $23.72 \pm 2.29^{\mathrm{b}}$ & $7.14 \pm 0.68^{\mathrm{a}}$ \\
\hline \multirow{4}{*}{ Ovine } & $\leq 2$ & $0.82 \pm 0.04^{\mathrm{e}}$ & $2.51 \pm 0.23^{\mathrm{f}}$ & $2.95 \pm 0.13^{\mathrm{bc}}$ \\
\hline & 3 & $2.23 \pm 0.18^{\mathrm{d}}$ & $5.27 \pm 0.48^{\mathrm{f}}$ & $4.40 \pm 0.36^{\mathrm{b}}$ \\
\hline & 4 & $4.91 \pm 0.46^{\mathrm{c}}$ & $12.33 \pm 1.15^{\mathrm{d}}$ & $6.21 \pm 0.58^{\mathrm{ab}}$ \\
\hline & $5 \leq$ & $10.29 \pm 0.94^{\mathrm{a}}$ & $20.85 \pm 1.90^{\mathrm{b}}$ & $8.30 \pm 0.79^{\mathrm{a}}$ \\
\hline \multirow{4}{*}{ Caprine } & $\leq 2$ & $1.14 \pm 0.10^{\mathrm{d}}$ & $1.90 \pm 0.12^{\mathrm{f}}$ & $2.86 \pm 0.17^{\mathrm{bc}}$ \\
\hline & 3 & $2.48 \pm 0.26^{\mathrm{c}}$ & $8.22 \pm 0.43^{\mathrm{e}}$ & $3.98 \pm 0.33^{b}$ \\
\hline & 4 & $7.71 \pm 0.65^{b}$ & $18.84 \pm 1.62^{\mathrm{c}}$ & $7.19 \pm 0.61^{\mathrm{a}}$ \\
\hline & $5 \leq$ & $9.23 \pm 0.87^{\mathrm{a}}$ & $23.33 \pm 2.21^{\mathrm{b}}$ & $8.08 \pm 0.69^{a}$ \\
\hline \multirow{4}{*}{ Camel } & $\leq 2$ & $0.14 \pm 0.01^{\mathrm{e}}$ & $0.92 \pm 0.08^{f}$ & $1.71 \pm 0.07^{\mathrm{d}}$ \\
\hline & 3 & $1.77 \pm 0.12^{\mathrm{d}}$ & $4.15 \pm 0.31^{\mathrm{e}}$ & $2.52 \pm 0.20^{\mathrm{bc}}$ \\
\hline & 4 & $3.10 \pm 0.25^{\mathrm{c}}$ & $10.02 \pm 0.88^{\mathrm{e}}$ & $4.95 \pm 0.41^{b}$ \\
\hline & $5 \leq$ & $4.01 \pm 0.21^{\mathrm{c}}$ & $14.44 \pm 1.26^{\mathrm{c}}$ & $5.23 \pm 0.47^{b}$ \\
\hline \multirow{4}{*}{ Buffalo } & $\leq 2$ & $1.02 \pm 0.52^{\mathrm{d}}$ & $1.26 \pm 0.11^{\mathrm{f}}$ & $2.73 \pm 0.18^{c}$ \\
\hline & 3 & $3.33 \pm 0.28^{\mathrm{c}}$ & $5.21 \pm 0.49^{\mathrm{e}}$ & $3.96 \pm 0.24^{\mathrm{bc}}$ \\
\hline & 4 & $8.25 \pm 0.76^{b}$ & $15.92 \pm 1.37^{\mathrm{c}}$ & $5.51 \pm 0.45^{\mathrm{b}}$ \\
\hline & $5 \leq$ & $12.02 \pm 1.04^{\mathrm{a}}$ & $28.61 \pm 1.02^{\mathrm{a}}$ & $8.24 \pm 0.65^{\mathrm{a}}$ \\
\hline
\end{tabular}

*Dissimilar small leathers in each column shows significant statistical difference $(P<0.05)$. 
Table 3. Seasonal distribution of toxic heavy metals in different types of raw milk samples.

\begin{tabular}{|c|c|c|c|c|}
\hline \multirow{2}{*}{$\begin{array}{l}\text { Types of milk } \\
\text { samples }\end{array}$} & \multirow{2}{*}{ Season } & \multicolumn{3}{|c|}{ Concentrations of heavy metals (Mean \pm SD, ppb) } \\
\hline & & $\mathrm{Cd}$ & $\mathrm{Pb}$ & $\mathrm{Hg}$ \\
\hline \multirow{4}{*}{ Bovine } & Winter & $2.12 \pm 0.17^{\mathrm{b}}$ & $3.61 \pm 0.32^{\mathrm{e}}$ & $2.99 \pm 0.21^{\mathrm{c}}$ \\
\hline & Spring & $10.17 \pm 1.00^{\mathrm{a}}$ & $22.11 \pm 2.02^{\mathrm{a}}$ & $7.03 \pm 0.55^{\mathrm{a}}$ \\
\hline & Summer & $9.01 \pm 0.65^{\mathrm{a}}$ & $20.36 \pm 1.54^{\mathrm{a}}$ & $6.80 \pm 0.59^{\mathrm{a}}$ \\
\hline & Autumn & $3.41 \pm 0.33^{\mathrm{b}}$ & $8.52 \pm 0.73^{\mathrm{d}}$ & $5.42 \pm 0.51^{\mathrm{a}}$ \\
\hline \multirow{2}{*}{ Ovine } & Spring & $2.49 \pm 0.22^{b}$ & $7.83 \pm 0.45^{\mathrm{d}}$ & $4.52 \pm 0.39^{\mathrm{ab}}$ \\
\hline & Summer & $7.05 \pm 0.61^{\mathrm{a}}$ & $17.96 \pm 1.22^{\mathrm{b}}$ & $7.17 \pm 0.67^{\mathrm{a}}$ \\
\hline \multirow{2}{*}{ Caprine } & Spring & $3.55 \pm 0.28^{\mathrm{b}}$ & $5.31 \pm 0.46^{\mathrm{d}}$ & $3.56 \pm 0.29^{\mathrm{bc}}$ \\
\hline & Summer & $8.14 \pm 0.43^{\mathrm{a}}$ & $20.20 \pm 1.55^{\mathrm{a}}$ & $7.33 \pm 0.51^{\mathrm{a}}$ \\
\hline \multirow{4}{*}{ Camel } & Winter & $0.72 \pm 0.05^{\mathrm{c}}$ & $1.24 \pm 0.10^{\mathrm{e}}$ & $1.09 \pm 0.08^{\mathrm{c}}$ \\
\hline & Spring & $3.98 \pm 0.25^{\mathrm{b}}$ & $14.03 \pm 1.14^{\mathrm{b}}$ & $5.18 \pm 0.46^{\mathrm{a}}$ \\
\hline & Summer & $3.03 \pm 0.21^{\mathrm{b}}$ & $11.56 \pm 0.92^{\mathrm{c}}$ & $4.85 \pm 0.39 \mathrm{a}^{\mathrm{b}}$ \\
\hline & Autumn & $1.63 \pm 0.18^{\mathrm{c}}$ & $5.10 \pm 0.42^{\mathrm{d}}$ & $2.96 \pm 0.21^{\mathrm{c}}$ \\
\hline \multirow{4}{*}{ Buffalo } & Winter & $1.22 \pm 0.09^{\mathrm{c}}$ & $1.20 \pm 0.14^{\mathrm{e}}$ & $2.80 \pm 0.19^{\mathrm{c}}$ \\
\hline & Spring & $12.00 \pm 1.01^{\mathrm{a}}$ & $25.59 \pm 2.12^{\mathrm{a}}$ & $8.11 \pm 0.60^{\mathrm{a}}$ \\
\hline & Summer & $10.36 \pm 0.93^{\mathrm{a}}$ & $17.08 \pm 1.62^{\mathrm{b}}$ & $5.77 \pm 0.47^{\mathrm{a}}$ \\
\hline & Autumn & $5.09 \pm 0.47^{b}$ & $6.38 \pm 0.52^{\mathrm{d}}$ & $4.04 \pm 0.31^{\mathrm{ab}}$ \\
\hline
\end{tabular}

*Dissimilar small leathers in each column shows significant statistical difference $(P<0.05)$.

technologies, these substances are becoming a part of agricultural products, including milk from cows, ewes, goats, buffalo and camels. Additionally, the presence of toxic heavy metals in milk causes no special changes in color, odor, taste and consolidation, and is considered a silent agent of toxicity [10]. Therefore, it is important to assess the concentrations of toxic heavy metals and especially $\mathrm{Cd}, \mathrm{Pb}$ and $\mathrm{Hg}$ in milk of animal species. Heavy metals are added to the environment in large quantities through atmospheric deposition, solid waste disposal, sludge application and wastewater irrigation. Animal feed, drinking water and environmental exposure, for example irrigation of agriculture land with sewage and industrial wastewater, might be sources of heavy metals in animal products such as milk. Consumption of milk from cattle and buffalo reared in the polluted sites leads to long exposure to these environmental heavy metals, which results in considerable human health hazards. Milk could also become contaminated during manufacturing and packaging. The sources of heavy metals are multiple and their entry into the dairy chain depends on biological variables such as the rate of absorption into the animal body. Table 1 represents the concentrations of toxic heavy metals in different types of raw milk samples. The mean concentrations of $\mathrm{Cd}, \mathrm{Pb}$ and $\mathrm{Hg}$ in all studied samples were $3.62 \pm 0.35,11.73 \pm 1.09$ and $4.35 \pm 0.42 \mathrm{ppb}$, respectively. In total, concentrations of $\mathrm{Cd}, \mathrm{Pb}$ and $\mathrm{Hg}$ had ranges of 0.06-14.03, 0.12-33.62 and 1.03-10.38 ppb, respectively. We found that bovine raw milk samples harbored the highest concentrations of $\mathrm{Cd}(4.05 \pm 0.38 \mathrm{ppb}), \mathrm{Pb}(12.36 \pm 1.21 \mathrm{ppb})$ and $\mathrm{Hg}$
(5.76 $\pm 0.53 \mathrm{ppb})$. Statistically significant differences were seen as types of raw milk samples and concentrations of toxic heavy metals $(P<0.05)$. Table 2 represents the senile distribution of toxic heavy metals in different types of raw milk samples. The highest mean concentrations of $\mathrm{Cd}, \mathrm{Pb}$ and $\mathrm{Hg}$ were detected in $5 \leq$ year-old buffalo (12.02 $\pm 1.04 \mathrm{ppb}), 5 \leq$ year-old buffalo $(28.61 \pm 1.02 \mathrm{ppb})$ and $5 \leq$ year-old ovine $(8.30 \pm 0.79 \mathrm{ppb})$ milk samples, respectively. We found that milk of $5 \leq$ year-old animals had the highest concentrations of all studied toxic heavy metals $(P<0.05)$. Table 3 represents the seasonal distribution of toxic heavy metals in different types of raw milk samples. The highest mean concentrations of $\mathrm{Cd}, \mathrm{Pb}$ and $\mathrm{Hg}$ were detected in raw buffalo milk samples collected in spring (12.00 \pm 1.01 , $25.59 \pm 2.12$ and $8.11 \pm 0.60 \mathrm{ppb}$, respectively). Raw milk samples collected in spring had the highest concentrations of toxic heavy metals, while those collected in winter had the lowest $(P<0.05)$. In keeping with this, there were no significant differences for the concentrations of all studied toxic heavy metals between spring and summer seasons $(P>0.05)$. The presence of toxic heavy metals in milk causes no special changes in color, odor, taste and consolidation of milk and is considered a silent agent to cause toxicity [10]. Therefore, it is important to assess the concentrations of toxic heavy metals and especially $\mathrm{Cd}, \mathrm{Pb}$ and $\mathrm{Hg}$ in milk of animal species. The present investigation showed that raw milk samples of bovine, ovine, caprine, camel and buffalo species harbored considerable amounts of $\mathrm{Pb}, \mathrm{Hg}$ and $\mathrm{Cd}$ toxic heavy metals. The mean concentrations of $\mathrm{Cd}, \mathrm{Pb}$ and $\mathrm{Hg}$ in bovine, ovine, 
Table 4. Standard allowed limit concentrations of $\mathrm{Cd}, \mathrm{Pb}$ and $\mathrm{Hg}$ in milk samples [13-21].

\begin{tabular}{|c|c|}
\hline Toxic heavy metals & Standard allowed limit (ppb) \\
\hline $\mathrm{Cd}$ & 1000 \\
\hline $\mathrm{Pb}$ & 0.01 \\
\hline $\mathrm{Hg}$ & 0.5 \\
\hline
\end{tabular}

caprine, camel and buffalo milk samples were $4.05 \pm 0.38$, $12.36 \pm 1.21$ and $5.76 \pm 0.53,3.41 \pm 0.31,11.94 \pm 1.92$ and $5.44 \pm 5.37, \quad 3.22 \pm 0.31, \quad 10.25 \pm 1.01$ and $5.10 \pm 0.50$, $1.22 \pm 0.11, \quad 3.14 \pm 0.26$ and $2.36 \pm 0.21$ and finally $3.73 \pm 0.34,12.04 \pm 1.19$ and $5.52 \pm 0.44 \mathrm{ppb}$, respectively. To the best of our knowledge, the present investigation is the first report of detection of $\mathrm{Cd}, \mathrm{Pb}$ and $\mathrm{Hg}$ in raw camel and buffalo milk samples in Iran. Furthermore, rare studies have been conducted in this field on ovine and caprine milk samples in Iran. The allowed limit concentrations of $\mathrm{Pb}, \mathrm{Cd}$ and $\mathrm{Hg}$ in milk were $1000 \mathrm{ppb}$ [11], $0.01 \mathrm{ppb}$ [11] and $0.5 \mathrm{ppb}$ [12], respectively. Thus, the mean concentrations of $\mathrm{Cd}$ and $\mathrm{Hg}$ elements were lower than standard allowed limits, while those of $\mathrm{Pb}$ were higher [11, 12] (Table 4). Rahimi (2013) [13] described that the mean concentrations of $\mathrm{Pb}$ and $\mathrm{Cd}$ in raw bovine, buffalo, caprine and ovine milk samples were $90.88 \pm 4.75,60.16 \pm 3.16,70.37 \pm 3.18$ and $120.1 \pm 5.63$ and $9.92 \pm 0.77,7.74 \pm 0.41,20.33 \pm 1.23$ and $30.31 \pm 1.53 \mathrm{ppb}$, respectively. Javed et al. (2009) [14] presented the mean concentrations of $\mathrm{Cd}$ in raw bovine and caprine milk samples as $7.07 \pm 0.14$ and $8.08 \pm 0.03 \mathrm{ppb}$, respectively, while those of $\mathrm{Pb}$ were $180.87 \pm 160.91$ and $420.68 \pm 40.05 \mathrm{ppb}$, respectively, which were much more than our findings. Najarnezhad et al. (2013) [15] showed that the mean concentrations of $\mathrm{Pb}, \mathrm{Cd}$ and $\mathrm{Hg}$ in raw bovine milk samples were $12.90 \pm 6.00 \mathrm{ppb}$, $0.30 \pm 0.30 \mathrm{ppb}$ and $3.10 \pm 0.30 \mathrm{ppb}$, respectively. They also showed that the mean concentrations of these trace elements in raw ovine milk samples were and $14.90 \pm 7.80 \mathrm{ppb}, 1.60 \pm 1.20 \mathrm{ppb}$ and $3.10 \pm 0.30 \mathrm{ppb}$, respectively, which all were lower than our findings. The mean concentrations of cow, buffalo, goat, sheep and camel milk samples in Pakistan [16] were of $\mathrm{Cd}$ in $76.07 \pm 6.06, \quad 117.11 \pm 8.08, \quad 74.34 \pm 3.52, \quad 10.01 \pm 1.00$ and $102.14 \pm 7.09 \mathrm{ppb}$, respectively. Mean concentrations of $\mathrm{Pb}$ and $\mathrm{Cd}$ in raw milk samples of cow, goat and sheep in Sudan [17] were 502.50, 74.48 and 30.23 and 0.60, 5.92 and $7.10 \mathrm{ppb}$, respectively. Camel milk samples harbored low concentrations of $\mathrm{Pb}(3.14 \pm 0.26 \mathrm{ppb}), \mathrm{Cd}$ $(1.22 \pm 0.11 \mathrm{ppb})$ and $\mathrm{Hg}(2.36 \pm 0.21 \mathrm{ppb})$ toxic heavy metals. Konuspayeva et al. (2009) [18] reported that the concentrations of $\mathrm{Pb}$ in raw camel milk samples of Kazakhstan were $25.02 \pm 1.91$ ppb. Contents of $\mathrm{Pb}$ and $\mathrm{Cd}$ in camel milk samples of another Iranian research were in the ranges of $2262 \pm 210.35$ to $8280 \pm 800.93 \mathrm{ppb}$ and $90.09 \pm 5.05$ to $720.14 \pm 70.40 \mathrm{ppb}$, respectively [19]. Nnadozie et al. (2014) [20] reported that the amount of $\mathrm{Cd}$ in camel milk in Nigeria was $191.11 \mathrm{ppb}$. Damarany
(2016) [21] reported that the overall mean of $\mathrm{Pb}$ and $\mathrm{Cd}$ contents in camel milk in Egypt were $1056 \pm 105.85$ and $8.00 \pm 0.21 \mathrm{ppb}$, respectively. The obtained results agreed with those reported by Saini et al. (2007) [22], Meldebekova et al. (2008) [23] and El-Bagermi et al. (2014) [24]. To the best of our knowledge, there were no previously published data on detection of $\mathrm{Hg}$ in camel milk samples. High concentrations of lead in camel milk for the reason of industrial and feeding animals in those areas and the existence of roads full of haze [25]. Concentrations of $\mathrm{Cd}, \mathrm{Pb}$ and $\mathrm{Hg}$ in buffalo milk samples of our research were $3.73 \pm 0.34,12.04 \pm 1.19$ and $5.52 \pm 0.44 \mathrm{ppb}$, respectively. Roy et al. (2009) [26] reported that the mean concentrations of $\mathrm{Pb}, \mathrm{Cd}$ and $\mathrm{Hg}$ toxic heavy metals in Indian raw buffalo milk samples were $48.03 \mathrm{ppb}, 6.06 \mathrm{ppb}$ and $0.73 \mathrm{ppb}$, respectively. Higher concentrations of $\mathrm{Pb}$ in buffalo milk samples (0.75 ppm) were also reported by Dwivedi et al. (2001) [27]. Similar concentrations of toxic heavy metals in buffalo milk were reported previously by Ismail et al. (2017) [28], Gaafar (2008) 29] and El-Ansary and El-Leboudy (2015) [30]. Buffalo breeding is often done around cities. Concentrations of toxic heavy metals of milk samples were higher when the protein and fat content increased. The relationship between the fat and protein of milk of animal species with concentrations of toxic heavy metals is another probable reason for differences found in the concentrations of toxic heavy metals [13, 31, 32]. Milk from older than 5-year-old animals had higher concentrations of $\mathrm{Cd}, \mathrm{Pb}$ and $\mathrm{Hg}$ $(P<0.05)$. Rubio et al. (1998) [33] reported that the $\mathrm{Pb}$ and $\mathrm{Cd}$ concentrations were significantly lower in milk samples obtained from cows aged $<5$ years $(17000 \mathrm{ppb}$ and $370 \mathrm{ppb}$, respectively) compared to cows aged $>5$ years (34000 ppb and $2087 \mathrm{ppb}$, respectively). The main reason for choosing the three metals $\mathrm{Pb}, \mathrm{Cd}$ and $\mathrm{Hg}$ in the present study is because of the higher impact of these three trace elements on human health. Additionally, the possibilities of detection of these trace elements in raw milk of bovine, ovine, caprine and camel species is higher than other types of toxic heavy metals. Previous studies revealed that in animals, Cd accumulates in kidney and liver and $\mathrm{Pb}$ accumulates in bone and tissues, metal concentration increases with age $[33,34]$. Additionally, older animals have the highest exposure to toxic heavy metals for a longer period of time. Therefore, the amounts of heavy metals shed in their milk samples were higher than in younger animals. Milk samples that were collected in the spring and summer had the highest concentrations of all studied heavy metals $(P<0.05)$. High concentrations of $\mathrm{Cd}$ and $\mathrm{Pb}$ in milk samples in warm seasons have been reported from Pakistan [35], Iran [15] and Lithuania [36]. Higher concentrations of toxic heavy metals in spring milk may be due to the differences in feeding patterns of dairy animals in Iran, differences in the amount of soil ingested by animals and vegetation types in different seasons, differences in the amounts of rainfall in various seasons and finally using chemical 
fertilizers, pesticides and insecticides in agricultural farms in this season $[13,31,32,37,38]$. A similar seasonal distribution of heavy metals in milk have been reported previously [7, 14, 39, 40].

In keeping with the high chemical contamination of food stuffs, microbial contamination has a higher importance. Several investigations have been conducted in this field and all of them have been demonstrated the high microbial contamination of diverse types of food samples [41-52].

\section{Conclusions}

In conclusion, results of the current research showed that $\mathrm{Cd}, \mathrm{Pb}$ and $\mathrm{Hg}$ concentrations in bovine, ovine, caprine, camel and buffalo milk samples were relatively high. Bovine and buffalo milk samples had the highest concentrations of $\mathrm{Cd}, \mathrm{Pb}$ and $\mathrm{Hg}$ heavy metals, while camels had the lowest. The mean concentrations of $\mathrm{Cd}$ and $\mathrm{Hg}$ heavy metals were lower than the allowed limits announced by the standard organizations, while those of $\mathrm{Pb}$ were higher. Additionally, there were no previously published data about the concentrations of $\mathrm{Hg}$ in buffalo and camel milk samples. Moreover, our data revealed marked seasonal and senile distribution of heavy metals with higher concentrations of $\mathrm{Cd}, \mathrm{Pb}$, and $\mathrm{Hg}$ in $5 \leq$ yearold animals and also in milk samples collected in spring and summer. These results highlight the importance of periodically monitoring levels of $\mathrm{Cd}, \mathrm{Pb}$ and $\mathrm{Hg}$ heavy metals in milk of bovine, ovine, caprine, buffalo and camel and also dairy products in Iran.

\section{Acknowledgements}

The authors would like to thank the staff of the Department of Toxicology and Health of the Islamic Azad University, Shahrekord Branch, Shahrekord, Iran.

\section{Conflict of Interest}

The authors declare no conflict of interest.

\section{References}

1. WATSON R.R., COLLIER R.J., PREEDY V.R. Nutrients in Dairy and Their Implications for Health and Disease. Elsevier Academic Press. 490, 2017.

2. ISMAIL A., RIAZ M., AKHTAR S., GOODWILL J.E., SUN J. Heavy metals in milk: global prevalence and health risk assessment. Toxin Rev. 1, 2017.

3. RANATHUNGA L., ESAKKIMUTHU M. A review on toxicity of heavy metals due to intake of contaminated bovine milk. Archives Agri Env Sci. 2, 244, 2017.

4. TUNEGOVA M., TOMAN R., TANČIN V. Heavy metals-environmental contaminants and their occurrence in different types of milk. Slovak J Animal Sci. 49, 122, 2016.
5. JAISHANKAR M., TSETEN T., ANBALAGAN N., MATHEW B.B., BEEREGOWDA K.N. Toxicity, mechanism and health effects of some heavy metals. Interdiscip Toxicol. 7, 60, 2014.

6. JAN A.T., AZAM M., SIDDIQUI K., ALI A., CHOI I., HAQ Q.M.R. Heavy metals and human health: mechanistic insight into toxicity and counter defense system of antioxidants. Int J Molecul Sci. 16, 29592, 2015.

7. HASHEMI M., SAKEHI T., AMINZARE M., RAEISI M., AFSHARI A. Contamination of Toxic Heavy Metals in Various Foods in Iran: a Review. J Pharm Sci Res. 9, 1692, 2017.

8. ZIARATI P. An Overview of the Heavy Metal Contamination in Milk and Dairy Products. Acta Sci Pharma Sci. 2, 08, 2018.

9. URSINYOVA M., MASANOVA V. Cadmium, lead and mercury in human milk from Slovakia. Food Add Contamin. 22, 579, 2005.

10. MAHMOUDI R., KAZEMINIA M., KABOUDARI A., PIR-MAHALLEH S., PAKBIN B. A review of the importance, detection and controlling of heavy metal in milk and dairy products. Malaysian J Sci. 36, 1, 2017.

11. CHARTER M.H. Food Safety and Toxicology. Wolf Publication. 54, 2000.

12. FAO. Food and Agriculture Organization of the United Nations, Codex Alimentarius Commission. The Secretariat of the Joint FAO/WHO Food Standards Program. Rome: FAO, 2013.

13. RAHIMI E. Lead and cadmium concentrations in goat, cow, sheep, and buffalo milks from different regions of Iran. Food Chem. 136, 389, 2013.

14. JAVED I., JAN I., MUHAMMAD F., KHAN M.Z., ASLAM B., SULTAN J.I. Heavy metal residues in the milk of cattle and goats during winter season. Bulletin Env Contamin Toxicol. 82, 616, 2009.

15. NAJARNEZHAD V., AKBARABADI M. Heavy metals in raw cow and ewe milk from north-east Iran. Food Add Contamin: Part B. 6, 158, 2013.

16. AHMAD I., ZAMAN A., SAMAD N., AYAZ M., RUKH S. Atomic Absorption Spectrophotometery Detection of Heavy Metals in Milk of Camel, Cattle, Buffalo and Goat from Various Areas of Khyber-Pakhtunkhwa (KPK). Pakistan J Anal Bioanal Tech. 8, 2, 2017.

17. ABDALlA M., HASSABO A., ELSHEIKH N. Assessment of some heavy metals in waste water and milk of animals grazed around sugar cane plants in Sudan. Livestock Res Rural Develo. 25, 12, 2013.

18. KONUSPAYEVA G., FAYE B., LOISEAU G., DIACONO E., AKHMETSADYKOVA S. Pollution of camel milk by heavy metals in Kazakhstan. Open Env Pollution Toxicol J. 1, 112, 2009.

19. MOSTAFIDI M., MOSLEHISHAD M., PIRAVIVANAK Z., POURETEDAL Z. Evaluation of mineral content and heavy metals of dromedary camel milk in Iran. Food Sci Technol. 36, 717, 2016.

20. NNADOZIE C., BIRNIN-YAURI U., MUHAMMAD C., UMAR A. Assessment of some diary products sold in Sokoto Metropolis, Nigeria. Int J Adv Res Chem Sci. 1, 1, 2014.

21. DAMARANY A.I. Concentrations of Sodium, Potassium, Copper, Zinc and Heavy Metals in Camel Milk Reared Under Pasture and Farm Conditions in South Egypt. J Animal Poultry Prod, Mansoura Univercity. 7, 2752016. 
22. SAINI N., BHATI A., SINGH N., TUTEJA F. Trace mineral and vitamin $\mathrm{C}$ content of camel milk: a comparative study. Vet Practitioner. 8, 20, 2007.

23. MELDEBEKOVA A., KONUSPAYEVA G., DIACONO E., FAYE B. Heavy Metals and trace elements content in camel milk and shubat from Kazakhstan. In: FAYE B., SINYAVSKIY Y., editors. Impact of Pollution on Animal Products. Netherland: Springer. 117. 2008

24. ELBAGERMI M., ALAJTAL A., EDWARDS H. A comparative study on the physicochemical parameters and trace elements in raw milk samples collected from Misurata-Libya. Sop Trans Analytic Chem. 1, 15, 2014.

25. KONUSPAYEVA G., JURJANZ S., LOISEAU G., BARCI V., AKHMETSADYKOVA S., MELDEBEKOVA A., FAYE B. Contamination of camel milk (heavy metals, organic pollutants and radionuclides) in Kazakhstan. J Env Protec. 2, 90, 2011.

26. ROY D., BHARATHIDHASAN S., MANI V., KAUR H., KEWALRAMANI N. Heavy metal contents in cow and buffalo milk samples from Haryana. Indian J Anim Nutr. 26, 29, 2009.

27. DWIVEDI S., SWARUP D., DEY S., PATRA R. Lead poisoning in cattle and buffalo near primary lead-zinc smelter in India. Vet Human Toxicol. 43, 93, 2001.

28. ISMAIL A., RIAZ M., AKHTAR S., FAROOQ A., SHAHZAD M.A., MUJTABA A. Intake of Heavy Metals through Milk and Toxicity Assessment. Pakistan J Zool. 49, 1413, 2017.

29. GAAFAR H. Accumulation of some heavy metals in hair, plasma and milk of cattle and buffaloes grazing berseem or reed plants in Egypt. Egyptian J Anim Prod. 45, 71, 2008.

30. EL-ANSARY M., EL_LEBOUDY A. Levels of Cadmium and Lead in raw cow and buffalo's milk samples collected from local markets of El-Behera Governorate. Alexandria J Vet Sci. 47, 2015.

31. RASHEED S., QAZI I.M., AHMED I., DURRANI Y., AZMAT Z. Comparative Study of Cottage Cheese Prepared from Various Sources of Milk. Proceedings of the Pakistan Academy of Sciences: Pakistan Academy Sci B Life Env Sci. 53, 269, 2016.

32. PARK Y., JUáREZ M., RAMOS M., HAENLEIN G. Physico-chemical characteristics of goat and sheep milk. Small Rum Res. 68, 88, 2007.

33. RUBIO M., SIGRIST M., ENCINAS T., BARONI E., CORONEL J., BOGGIO J., BELDOMENICO H. Cadmium and lead levels in cow's milk from a milking region in Santa Fe, Argentine. Bulletin Env Contamin Toxicol. 60, 164, 1998.

34. CAGGIANO R., SABIA S., D'EMILIO M., MACCHIATO M., ANASTASIO A., RAGOSTA M., PAINO S. Metal levels in fodder, milk, dairy products, and tissues sampled in ovine farms of Southern Italy. Env Res. 99, 48, 2005.

35. YOUNUS M., ABBAS T., ZAFAR M., RAZA S., KHAN A., SALEEM A., IDREES M., NISA Q., AKHTAR R., SALEEM G. Assessment of heavy metal contamination in raw milk for human consumption. South African J Animal Sci. 46, 166, 2016.

36. VALIUKENAITE R., STANKEVICIENE M., STANKEVICIUS H., SKIBNIEWSKA K.A. Lead and cadmium levels in raw cow's milk in Lithuania determined by inductively coupled plasma sector field mass spectrometry. Polish J Food Nutr Sci. 15, 243, 2006.

37. BARLOWSKA J., LITWINCZUK Z., KROL J., KEDZIERSKA-MATYSEK M. Fatty acid profile and minerals content in milk from cows of various breeds over spring-summer feeding period. Polish J Food Nutr Sci. 15, 13, 2006.

38. SINGH A., SHARMA R.K., AGRAWAL M., MARSHALL F.M. Health risk assessment of heavy metals via dietary intake of foodstuffs from the wastewater irrigated site of a dry tropical area of India. Food Chem Toxicol. 48, 611, 2010.

39. ASLAM B., JAVED I., KHAN F.H. Uptake of Heavy Metal Residues from Sewerage Sludge in the Milk of Goat and Cattle during Summer Season. Pakistan Vet J. 31, 2011.

40. MUHIB M.I., CHOWDHURY M.A.Z., EASHA N.J., RAHMAN M.M., SHAMMI M., FARDOUS Z., BARI M.L., UDDIN M.K., KURASAKI M., ALAM M.K. Investigation of heavy metal contents in Cow milk samples from area of Dhaka, Bangladesh. Int J Food Contamin. 3, $16,2016$.

41. HEMMATINEZHAD B., KHAMESIPOUR F., MOHAMMADI M., SAFARPOOR DEHKORDI F., MASHAK Z. Microbiological investigation of O-serogroups, virulence factors and antimicrobial resistance properties of Shiga toxin-producing Escherichia coli isolated from ostrich, turkey and quail meats. J Food Safety. 35, 491, 2015.

42. ATAPOOR S., DEHKORDI F.S., RAHIMI E. Detection of Helicobacter pylori in various types of vegetables and salads. Jundishapur J Microbiol. 7, e10013, 2014.

43. DEHKORDI F.S., PARSAEI P., SABERIAN S., MOSHKELANI S., HAJSHAFIEI P., HOSSEINI S.R., BABAEI M., GHORBANI M.N. Prevalence study of Theileria annulata by comparison of four diagnostic techniques in southwest Iran. Bulgar J Vet Med. 15, 123, 2012.

44. RAHIMI E., SEPEHRI S., DEHKORDI F.S., SHAYGAN S., MOMTAZ H. Prevalence of Yersinia species in traditional and commercial dairy products in Isfahan Province, Iran. Jundishapur J Microbiol. 7, e9249, 2014.

45. MOMTAZ H., RAHIMIAN M.D., SAFARPOOR DEHKORDI F. Identification and characterization of Yersinia enterocolitica isolated from raw chicken meat based on molecular and biological techniques. J Appl Poultry Res. 22, 137, 2013.

46. SAFARPOOR DEHKORDI F., BARATI S., MOMTAZ H., HOSSEINI AHARI S.N., NEJAT DEHKORDI S. Comparison of shedding, and antibiotic resistance properties of Listeria monocytogenes isolated from milk, feces, urine, and vaginal secretion of bovine, ovine, caprine, buffalo, and camel species in Iran. Jundishapur J Microbiol. 6, 284, 2013.

47. GHORBANI F., GHEISARI E., DEHKORDI F.S. Genotyping of vacA alleles of Helicobacter pylori strains recovered from some Iranian food items. Trop J Pharm Res. 15, 1631, 2016.

48. DEHKORDI F.S., KHAMESIPOUR F., MOMENI M. Brucella abortus and Brucella melitensis in Iranian bovine and buffalo semen samples: The first clinical trial on seasonal, Senile and geographical distribution using culture, conventional and real-time polymerase chain reaction assays. Kafkas Univ Vet Fak Dergisi. 20, 821, 2014.

49. DEHKORDI F.S., HAGHIGHI N., MOMTAZ H., RAFSANJANI M.S., MOMENI M. Conventional vs realtime PCR for detection of bovine herpes virus type 1 in aborted bovine, buffalo and camel foetuses. Bulgar J Vet Med. 16, 102, 2013. 
50. NEJAT S., MOMTAZ H., YADEGARI M., NEJAT S., SAFARPOUR DEHKORDI F., KHAMESIPOUR F. Seasonal, Geographical, Age and Breed Distributions of Equine Viral Arteritis in Iran. Kafkas Univ Vet Fak Dergisi. 21, 111, 2015.

51. DEHKORDI F.S., VALIZADEH Y., BIRGANI T.A., DEHKORDI K.G. Prevalence Study of Brucella melitensis and Brucella abortus in cow's milk using dot enzyme linked immuno sorbent assay and duplex polymerase chain reaction. J Pure Appl Microbiol. 8, 1065, 2014.

52. RAHIMI E., YAZDANPOUR S., DEHKORDI F.S Detection of Toxoplasma gondii antibodies in various poultry meat samples using enzyme linked immuno sorbent assay and its confirmation by polymerase chain reaction. J Pure Appl Microbiol. 8, 421, 2014. 